\title{
ENDOTHELIAL DYSFUNCTION AND ITS MANAGEMENT IN PATIENTS WITH ACUTE MYOCARDIAL INFARCTION COMBINED WITH METABOLIC SYNDROME
}

\author{
I.O. Yastremska \\ I. HORBACHEVSKY TERNOPIL NATIONAL MEDICAL UNIVERSITY, TERNOPIL, UKRAINE
}

Background. Oxidative stress, endothelial dysfunction, dyslipidemia and low-grade inflammation induce the disorders of energy metabolism and ischemic damage to cardiomyocytes. It is an essential issue in pathogenesis of acute coronary syndrome/myocardial infarction (ACS/MI).

Objective. The aim of the study was to improve the existing pharmacological therapy in patients with ACS/ MI combined with metabolic syndrome (MS).

Methods. The study enrolled 95 patients with acute myocardial infarction. The patients were divided into 2 groups depending on concomitant metabolic syndrome. All groups were divided to subgroups, where patients received typical standard treatment according to the Ukrainian unified and modified treatment regimen with addition of L-arginine and L-carnitine.

Results. In 79.2\% of patients with ACS/MI + MS the course of underlying disease was associated with various complications: pericarditis epistenocardica was diagnosed in 39.8\% of patients; arrhythmias were present in $35.5 \%$ of patients of the main group; left ventricular aneurysm was present in $15.9 \%$ of patients. At the same time, significant changes in the indicators of vascular endothelial function in patients with ACS (MI) were revealed (the level of endothelin-1 in the blood plasma was in 2.1 times higher than the reference norm) that was the justification for inclusion of L-arginine and L-carnitine in the complex therapy of comorbid patients.

Conclusions. The multi-modality treatment with inclusion of L-arginine and L-carnitine facilitated restoration of energy supply of myocardial contractility, endothelial function of blood vessels, and antioxidant protection of the body and ultimately resulted in a more favorable course of this comorbid problem.

KEYWORDS: myocardial infarction; metabolic syndrome; endothelial dysfunction; L-arginine; L-carnitine.

\section{Introduction}

The rupture of the atheromatous plaque and formation of coronary clot, which causes progressive stenosis, is considered the main cause of acute myocardial infarction (MI). However, the recently discussed pathogenetic factors include peroxide stress and endothelial dysfunction, dyslipidemia and low-intensity systemic inflammation underlying the disorders of energy metabolism and ischemic damage to cardiomyocytes. The aforementioned pathogenetic mechanism behind the development of acute coronary syndrome/myocardial infarction (ACS/MI) provides a possibility of management of these pathogenetic processes with metabolic and cytoprotective pharmacological therapy. In addition to that, the main risk factors for coronary heart disease and

Corresponding author: Yastremska Iryna, PhD student of the Department of Emergency and Medical Care, I. Horbachevsky Ternopil National Medical University, Ternopil, Ukraine. E-mail: yastremskaio@tdmu.edu.ua myocardial infarction as its life-threatening manifestation are obesity, hypertension, dyslipidemia, insulin resistance and diabetes, which as a whole can be components of metabolic syndrome (MS), the latter diagnosed in $28-35 \%$ patients with myocardial infarction $[1,4,13]$. The causes of MS, including insulin resistance, hyperinsulinemia and chronic inflammation simultaneously trigger and maintain high levels of atherogenesis, endothelial dysfunction and evoke coronary plaque instability as well as processes of thrombogenesis $[6,7,8]$. That is why a differentiated approach to treatment of patients with ACS/MI (with due consideration for comorbidities) is a priority at present stage. Both L-carnitine and L-arginine have been proved to be very promising metabolic drug products, which occur naturally in human body. They manifest their effects as active regulators of intermediary metabolism and energy-supplying processes [7, 12, 14]. However, their main physiological role includes 
regulation of functional state of blood vessels and maintaining adequate microcirculation in the organs and tissues of the body $[9,11]$. The above facts have become a rationale for studies of clinical efficacy and possibilities for correction of metabolic and endothelial disorders in patients with ACS/MI.

The aim of the study was to improve the existing therapeutic programs for ACS/MI combined with metabolic syndrome (MS).

\section{Methods}

The study enrolled 95 patients with acute myocardial infarction. The patients were divided into 2 groups depending on whether they had metabolic syndrome. The main study group involved 53 patients with ACS/MI+MS. The control group included 42 patients with ACS/MI, who were not diagnosed with MS; 32 patients in the main group and 22 patients in the control group received standard treatment for myocardial infarction according to the Unified Protocols of the Ministry of Health of Ukraine [5]. Other 21 patients in the main group and 20 patients in the control group received a modified treatment regimen with addition of L-arginine $4.2 \mathrm{~g}$ and L-carnitine $2.0 \mathrm{~g}$ supplied as solution for infusions $100 \mathrm{~mL}$ administered intravenously once a day as a 5-day course. Most of study participants were males (87.5\%) of productive age, $57.54 \pm 8.02$ years old on average.

The diagnosis of acute MI was verified according to the 2017 ESC Guidelines [2] in the presence of a typical anginal attack, MI-specific ECG changes with time (reciprocal ST displacement) and the signs of resorption-necrosis syndrome. The diagnosis was confirmed by means of laboratory tests, ECG and imaging tests. Quantitative determination of troponin T was performed using an electro chemiluminescent biochemical analyzer Elecsys 2010 by Roche/Hitachi (Switzerland). Troponin test results above the reference value of $14.0 \mathrm{ng} / \mathrm{mL}$ were assessed as positive.

Patient assessments included general clinical examination, laboratory tests (hematology, MB fraction of creatine phosphokinase (CPK$M B)$, troponin $T$, oxygen saturation of arterial blood (SpO2), ECG in 12 standard leads, etc. and B-mode cardiac ultrasound imaging on Aloka SSD - 2000 unit (USA) with determination of linear and volumetric parameters of the left ventricle, as well as global (assessed by ejection fraction, EF) and local myocardial contractility using the Simpson's biplane method. The diastolic function of the left ventricle was assessed by the isovolumic relaxation time (IVRT) of the left ventricle, delay time for early left ventricular filling (DT), maximal early filling velocity (E) and maximal atrial systole filling velocity of the left ventricle (A). Plasma level of endothelin-1 (ET-1) was evaluated by the ELISA kits by Amersham Pharmacia Biotech; the stable NO metabolites content was determined by the Griess reagent reaction [2]. The number of nitrites was measured using a calibration graph. The abovementioned tests were repeated on day 14 and day 28 and tracked as they changed with time. Statistical data analysis was performed using the STATISTICA statistical package (by StatSoft, USA, v 6.0).

\section{Results}

Uncomplicated course of myocardial infarction was established in 17 patients (40\%) of the control groups. In 42 patients with MI+MS $(79.2 \%)$, the course of their underlying disease was accompanied by various complications. Thus, the patients of the test group were substantially more likely to develop pericarditis epistenocardica (21 (39.8\%) patients) than those in the control group (8 (19\%) patients). Conduction disorders or arrhythmias manifested as paroxysmal tachyarrhythmia, transient atrioventricular block and bundle branch blocks; extrasystole arrhythmia were also more frequent in the patients of the main group (78.5\%) and significantly less frequent in the patients with MI without MS (52\%). These results are presented in Fig. 1.

Acute left ventricular failure accompanied the course of MI in all patients of both groups; however, Killip I and Killip II acute heart failure (according to the Killip-Kimball Classification, 1972) was substantially more frequent in the patients of the control group. Impaired systolic and diastolic functions of the left ventricle were simultaneously observed in the patients of the main group and the control group. That is, there was a significantly more significant reduction in myocardial contractility ( $E F=42.12 \pm 1.13 \%)$ compared to the control group ( $\mathrm{EF}=48.23 \pm 1.16 \%)$. These changes were closely related to the more pronounced processes of left ventricular remodeling during the acute period of myocardial infarction in the patients of the main group. In particular, the increase in left ventricular internal diastolic dimension (the left ventricular end-diastolic diameter, LVEDD) was $5.62 \pm 0.21 \mathrm{~cm}$ in the main group and $4.71 \pm 0.24 \mathrm{~cm}$ in the control group $(p<0.05)$. The developing diastolic dysfunction was suggested by changes in the 


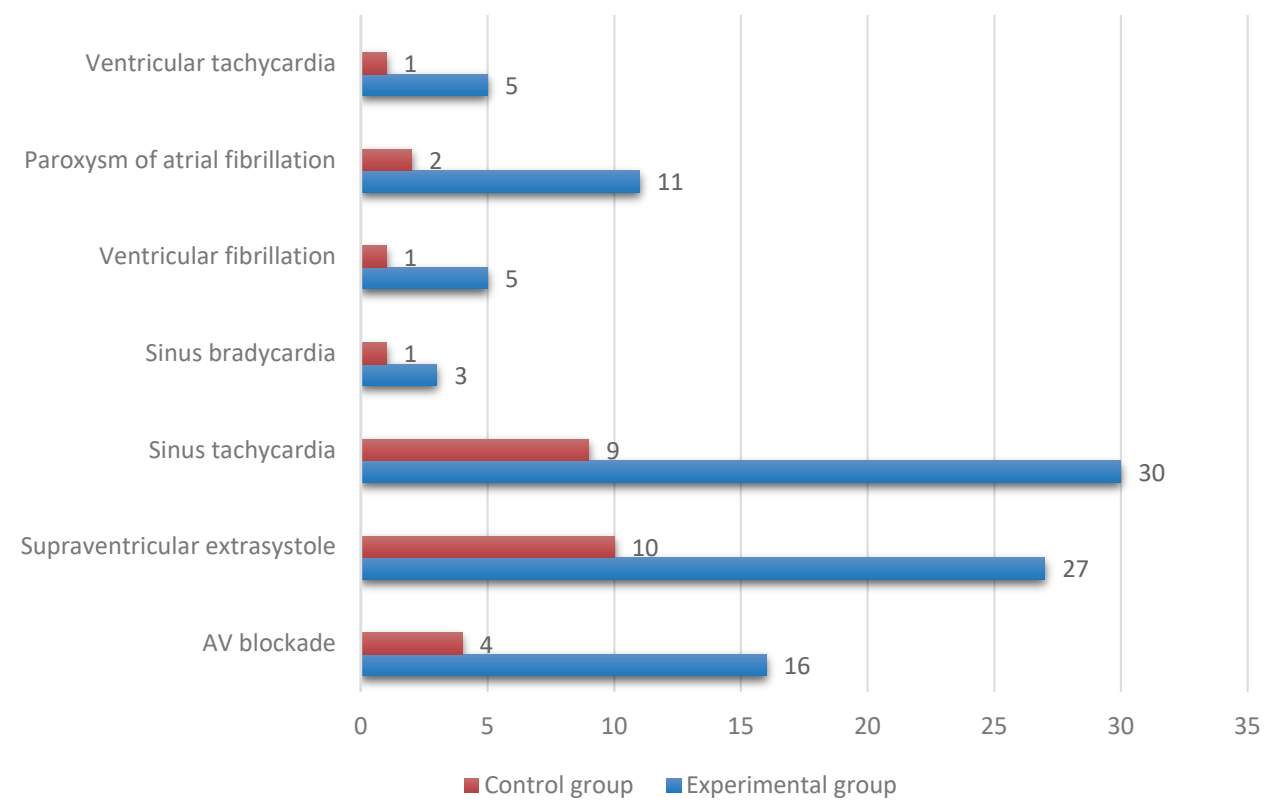

Fig 1. Frequency of arrhythmias and conduction disorders in the patients with acute coronary syndrome (myocardial infarction).

isovolumic relaxation times (IVRT) in the main group (63.23 $\pm 0.41 \mathrm{msec}$ ) and the control group $(68.12 \pm 0.36 \mathrm{msec})$, as well as by delay time of early diastolic transmitral flow (DT) in the compared groups $(178.11 \pm 0.54 \mathrm{msec}$ and $182.43 \pm 0.37 \mathrm{msec}$, respectively).

After completion of a standard MI treatment, the patients of the control group experienced significant improvement of hemodynamic parameters. Relatively, there was an increase in left ventricular ejection fraction, a reduction in LVEDD and improvement in left ventricular diastolic function parameters, i.e. IVRT and DT, compared to the MI+MS patients $(p<0.05)$. However, the patients with myocardial infarction combined with MS experienced more frequent complications in a setting of standard treatment. This is because of special characteristics of carbohydrate metabolism in the patients with MS, which are manifested by insulin resistance and compensatory hyperinsulinemia (which activates the sympathoadrenal system), as well as by a combination of this pathogenetic mechanism with other pathogenetic factors of ischemia (an increase in lipid peroxidation and endothelial dysfunction) that is accompanied by a more prolonged activation of oxidative processes and inhibited activity of enzymes in the antioxidant protection system. The abnormal processes in the heart enhanced causing a significant reduction of myocardial contractility and substantial changes in electrolyte stability of the heart that contributed to life-threatening disorders of rhythm and conductivity against the backdrop of unstable hemodynamics $[9,11]$.

As a consequence, L-arginine and L-carnitine are promising treatments. In addition to their pronounced metabolic and energy-producing activity, these substances restore endothelial function of blood vessels, exert antioxidant effects and prevent irreversible ischemic and reperfusion damage, limit the zone of myocardial necrosis, improve cellular adjustment to functioning under hypoxia and inhibit abnormal cardiac remodeling. One of the mechanisms behind such therapeutic effect is the ability of L-arginine and L-carnitine to inhibit the formation of radicals during breakdown of fatty acids thereby reduce the damaging effects of peroxidation byproducts on the functional status of ion channels in the cells $[1,3,17]$.

Thus, the results of this study have demonstrated that a multi-modality therapeutic program with inclusion of $L$-arginine and L-carnitine in the patients of the main group had a substantial effect on restoration of systolic-diastolic function of the heart: the parameters of systolic and diastolic function of the heart returned to normal already within 28 days of treatment. That is, the linear dimensions of cardiac cavities changed insignificantly; thus, we may assume that the positive changes in EF, LVEDD, IVRT and DT compared to their respective baseline levels were driven by remodeling and restoration of functional status in zones of myocardial ischemia and hibernation [10]. 
The changes in the parameters of endothelial function of blood vessels were also assessed in the patients with ACS/MI as part of the study. The baseline levels of these parameters did not differ in between. However, they were significantly changed compared to the reference values. Thus, plasma levels of endothelin-1 in the patients with ACS/MI at hospitalization were in 2.1 times above the reference value $(0.96 \pm 0.04 \mathrm{ng} / \mathrm{mL}$ and $0.46 \pm 0.03 \mathrm{ng} / \mathrm{mL}$, respectively). There were no significant changes in endothelin-1 (ET-1) activity immediately after emergency angioplasty of the coronary vessel and its stenting. That is, the levels of endothelin were substantially reduced in the control group patients who received per-protocol pharmacological treatment. However, by the end of the in-patient treatment period, the levels of endothelin have not reached those of healthy individuals (0.66 $\pm 0.06 ; p>0.05)$.

In contrast, the patients of the test group, whose multi-modality treatment included the course of therapy with L-arginine and L-carnitine during the next 10 days of the in-patient treatment period, had a $33.3 \%$ reduction in ET-1 activity $(p<0.05)$, and after one month of treatment its plasma levels significantly decreased by additional $43 \%$ and reached the level of healthy individuals $(0.52 \pm 0.05 \mathrm{ng} / \mathrm{mL} ; p>0.05)$. Hence, the use of combination drug therapy with inclusion of L-arginine and L-carnitine in patients with ACS/MI provided for a rapid (over 10 days) reduction and complete restoration (over 28 days) of plasma endothelin-1 levels in these patients. Along with changes in endothelin-1 activity in patients with ACS/MI during exacerbation of the disease, there was an abrupt reduction in metabolites of nitric oxide (NOE=17.75 $\pm 0.42 \mu \mathrm{mol} / \mathrm{L}$, the normal level of $36.92 \pm 0.37 \mu \mathrm{mol} / \mathrm{L})$, which could suggest pronounced microcirculatory disorders in these patients.

Thus, there was an almost two-fold baseline decrease in plasma levels of nitrates and nitrites in the patients of both groups, i. e. their total plasma levels were reduced by $45.0 \%$. However, conventional per-protocol treatment did not lead to complete restoration of endothelial function of blood vessels in this group of patients with ACS/MI; the total plasma level of metabolites of nitric oxide in these patients was by $19 \%$ below the reference value $(p<0.05)$. At the same time, the use of combination drug therapy with inclusion of L-arginine and L-carnitine had a substantial effect on plasma levels of nitrites and nitrates in the patients of the test group. The levels of these substances were significantly increased already before 10 days of treatment; after completion of the in-patient phase of combination drug therapy they reached the reference level.

\section{Discussion}

Therefore, since patients with ACS/MI + MS were diagnosed with pronounced baseline changes of morphological and functional parameters of the heart, post-infarction remodeling with compromised systolic and diastolic functions of the heart, as well as development of heart failure and endothelial dysfunction (which were retained immediately after emergency percutaneous procedures), these findings provided a rationale for inclusion of parenteral L-arginine and L-carnitine to the per-protocol therapeutic program. Standard therapy was established to lack sufficient hemodynamic efficacy in this patient cohort. Only enhancing standard therapy by adding L-arginine and L-carnitine caused significant EF and DT increases, LVEDD reduction and E/A ratio reduction and improved post-infarction cardiac remodeling, ultimately evident as a significant improvement of EF, myocardial contractility and diastolic dysfunction. In our opinion, the positive effect of the suggested treatment for inotropic heart function and a significant reduction in incidence and severity of reperfusion arrhythmias were achieved precisely by means of the cardiometabolic effect of L-carnitine, which, as reported by many researchers, is significant in energy metabolism in the myocardium by transferring free fatty acids from the cytosol inside the mitochondria thereby ensuring bio-availability of the highenergy substrate for oxidative metabolism in the cardiomyocyte $[8,16]$. In addition, by facilitating oxidation of long-chain fatty acids and by modulating the $\mathrm{COA} / \mathrm{COA}-\mathrm{SH}$ ratio, this compound is taking part in binding of acyl residues in peroxisomes and mitochondria and has a positive effect on amino acid metabolism by assimilating the pool of free radical compounds. This ensures stabilization of organelles and cellular membranes and prevents accumulation of fatty acid esters in the cytoplasm of cardiomyocytes, which may lead to fatal ventricular arrhythmias [15]. During the study it was also established that patients of the test group, whose multi-modality treatment included additional L-arginine and L-carnitine, had significantly lower ET-1 activity, while plasma levels of nitric oxide metabolites increased rea- 
ching the levels of healthy individuals ( $p>0.05)$. In other words, such multi-modality treatment in patients with ACS/MI contributed to a rapid and complete recovery of the study parameters of endothelial function of blood vessels. The treatment outcomes are associated with the use of L-arginine as a principal substrate for the synthesis of nitric oxide. The fundamental physiological role of nitric oxide is to regulate the functional status of blood vessels and to provide an adequate level of microcirculation in organs and tissues of the body $[9,11,14]$.

Thus, the conclusion may be drawn that the presence of a concomitant metabolic syndrome has a substantial impact on the course of acute myocardial infarction and is accompanied by a significantly higher complication rate. These patients have more severe disorders in the lipid peroxidation system and a reduced activity of antioxidant defense, which disrupts endothelial functions of blood vessels and causes deterioration of microcirculation. At the same time, significant reductions in systolic and diastolic functions of the myocardium have been observed in patients with MI+MS as a result of impaired remodeling of cardiac chambers and changes in their linear and geometric parameters. The combination treatment of MI+MS patients with inclusion of L-arginine and L-carnitine facilitates restoration of energy supply of myocardial contractility, endothelial function of blood vessels and antioxidant defense of the body, which results in a more favorable course of this comorbid problem.

\section{Conclusions}

The patients with myocardial infarction combined with metabolic syndrome were likely to develop disorders of central and peripheral hemodynamics and endothelial function of blood vessels. These circumstances significantly exaggerate the clinical course of the underlying morbidity, additionally enhance the disorders of systolic and diastolic cardiac function and cause more frequent complications of ACS/MI. A comprehensive therapeutic program for patients with ACS/MI+MS enhanced by inclusion of L-arginine and L-carnitine facilitates restoration of endothelial function of blood vessels and antioxidant defense of the body and increases the energy supply of cardiomyocytes, which is accompanied by improved myocardial contractility.

\section{Acknowledgements}

The author acknowledges Mykola Shved (MD, Ph.D., DSc, Professor) for assistance in preparation of this article.

\section{Funding}

This research received no external funding. Conflict of Interests

The author declares no conflict of interest.

\title{
ЕНДОТЕЛІАЛЬНА ДИСФУНКЦІЯ ТА ШЛЯХИ ЇЇ КОРЕКЦІЇ У ХВОРИХ НА ГОСТРИЙ ІНФАРКТ МІОКАРДА В ПОЄДНАННІ 3 МЕТАБОЛІЧНИМ сИНДРОМОМ.
}

\author{
Ястремська I.O. \\ ТЕРНОПІЛЬСЬКИЙ НАЦІОНАЛЬНИЙ МЕДИЧНИЙ УНІВЕРСИТЕТ IМЕНІ І.Я. ГОРБАЧЕВСЬКОГО, \\ ТЕРНОПІЛЬ, УКРАЇНА
}

Вступ. Окислювальний стрес, дисфункція ендотелію, дисліпідемія та низькоінтенсивне запалення спричиняють порушення енергетичного обміну та ішемічне ураження кардіоміоцитів, що є важивою ланкою у патогенезі гострого коронарного синдрому / інфаркту міокарда (ГКС / IM).

Мета дослідження - удосконалити існуючі лікувальні програми ГКС(IM) у поєднанні з метаболічним синдромом (MC).

Методи. У дослідженні взяли участь 95 пацієнтів з гострим інфарктом міокарда. Пацієнтів розподілили на 2 групи залежно від наявності супутнього метаболічного синдрому. Усі групи були розділені на підгрупи, де пацієнти отримували стандартне протокольне лікування згідно Уніфікованого протоколу МОЗ України та модифікована схеми лікування з додаванням L-аргініну та L-карнітину.

Результати дослідження. У хворих на IM із супутнім МС основне захворювання перебігало з різними ускладненнями у 79,2 \%: епістенокардитичний перикардит був у 39,8 \%; порушення ритму або 
провідності наявні у 35,5 \%; аневризма лівого шлуночка -у 15,9 \% хворих. Одночасно виявлено суттєві зміни у показниках ендотеліальної функції судин у хворих на ГКС(IM), що стало обґрунтуванням для включення в комплексну терапію коморбідних хворих курсу L-аргініну та L-карнітину.

Висновки. Комплексне лікування хворих на IM в поєднанні з MC із включеням L-аргініну та L-карнітину сприяло відновленню енергозабезпечення скоротливості міокарда, ендотеліальної функції судин, антиоксидантного захисту організму, що в результаті забезпечувало більш сприятливий перебіг даної коморбідної патології.

КЛЮЧОВІ СЛОВА: інфаркт міокарда; метаболічний синдром; ендотеліальна дисфункція; L-аргінін; L-карнітин.

Information about the authors

Yastremska Iryna - PhD student of the Department of Emergency and Medical Care, I. Horbachevsky Ternopil National Medical University, Ternopil, Ukraine.

ORCID: 0000-0001-6884-6705, e-mail: yastremskaio@tdmu.edu.ua

\section{References}

1. Batushkin VV. [Cytoprotection in acute myocardial infarction after the discovery of infarctdependent artery: new horizons]. Liky Ukrainy. 2017;8(214):33-40. (In Ukrainian)

2. Thiele H, Desch S, de Waha S. Acute myocardial infarction in patients with ST-segment elevation myocardial infarction: ESC guidelines 2017. Herz. 2017 Dec 1;42(8):728-38.

3. Parkhomenko OM, Kozhukhov SN, Lutay YaM. [Rationale and design of multicenter randomized study PROTECT - study of the effectiveness and safety of quercetin in patients with acute myocardial infarction]. Ukrainian Journal of Cardiology. 2016;(3): 31-6. (In Ukrainian)

4. Selyuk MM, Kozachok MM, Levkin IM, Selyuk OV. Selection of the optimal combination of metabolic drugs for the treatment of patients with cardiovascular pathology. Family Medicine. 2017; 2(70):60-4. (In Ukrainian)

5. Acute coronary syndrome with ST segment elevation: Unified clinical protocol of emergency, primary, secondary and tertiary care. - Ministry of Health of Ukraine. 2017: 78. (In Ukrainian)

6. Shved MI, Tsuglevich LV, Geryak SM. Clinical efficacy of cardiocytoprotective therapy in patients with acute coronary syndrome (myocardial infarction), who underwent balloon angioplasty and coronary artery stenting. Archive of Clinical Medicine.2019;(1):31-7.

DOI: https://doi.org/10.21802/acm.2019.1.2

7. Astashkin EI, Glezer MG. Role of L-carnitine in energy metabolism cardiomyocytes and treatment of diseases of cardiovascular system. Cardiology and cardiovascular surgery. 2012;6(2):58-65.

8. DiNicolantonio J, Lavie CJ, Fares H, Menezes AR, O'Keefe JH. L-carnitine in the secondary prevention of cardiovascular disease: systematic review and meta-analysis. In Mayo Clinic Proceedings 2013 Jun 1 (Vol. 88, No. 6, pp. 544-551). Elsevier.

9. Celermajer DS. Endothelial dysfunction: does it matter? Is it reversible?. Journal of the American College of Cardiology. 1997 Aug;30(2):325-33.

DOI: https://doi.org/10.1016/S0735-1097(97) 00189-7

10. Colonna $P$, Iliceto S. Myocardial infarction and left ventricular remodeling: results of the CEDIM trial. American heart journal. 2000 Feb 1;139(2): s124-30.

DOI: https://doi.org/10.1067/mhj.2000.103918

11. Haynes WG, Webb DJ. Endothelin as a regulator of cardiovascular function in health and disease. Journal of Hypertension. 1998 Aug 1;16(8):1081-98.

DOI: https://doi.org/10.1097/00004872199816080-00001

12. George J, Shmuel SB, Roth A. L-arginine attenuates lymphocyte activation and antioxidized LDL antibody levels in patients undergoing angioplasty. Atherosclerosis. 2004;174: 323-327.

DOI: https://doi.org/10.1016/j.atherosclerosis. 2004.01.025

13. Ibanez B, James S, Agewall S. 2017 ESC Guidelines for the management of acute myocardial infarction in patients presenting with ST-segment elevation: The Task Force for the management of 
acute myocardial infarction in patients presenting with ST-segment elevation. Eur Heart J. 2018;2: 119-177.

DOI: https://doi.org/10.1093/eurheartj/ehx393.

14. Opie LH. Role of carnitine in fatty acid metabolism of normal and ischemic myocardium. Am Heart J. 1997;97 (3):375-88. 90440-X

DOI: https://doi.org/10.1016/0002-8703(79)

15. Rizzon P, Biasko G, Biase MDi. High doses of L-carnitine in acute myocardial infarction: metabolic and antiarrhythmic effects. Eur Heart J.1989;10 (6):502-8.

DOI: https://doi.org/10.1093/oxfordjournals. eurheartj.a059519
16. Shug A, Thomsen J, Folts J. Changes in tissue levels of carnitine and other metabolites during myocardial ischemia and anoxia. Arch Biochem Biophys. 1998;187(1):25-33.

90003-6

DOI: https://doi.org/10.1016/0003-9861(78)

17. Hicks JJ, MontesCortes DH, Cruz-Dominguez MP. Antioxidants decrease reperfusion induced arrhythmias in myocardial infarction with ST-elevation. Frontiers in Bioscience. 2007;12:2029-37.

DOI: https://doi.org/10.2741/2208

Received 7 Oct 2020; revised 11 Nov 2020; accepted 1 Dec 2020.

This is open access article distributed under the Creative Commons Attribution License, which permits unrestricted use, distribution, and reproduction in any medium, provided the original work is properly cited. 